\title{
Management Regions, Statistical Areas and Fishing Grounds: Criteria for Dividing up the Sea
}

\author{
Patricia M. Clay \\ National Marine Fisheries Service, Northeast Fisheries Science Center \\ 166 Water St., Woods Hole, MA 02543, USA
}

\begin{abstract}
The delimitation of areas of the sea is common practice in fisheries management, particularly when addressing problems associated with size selection and by-catch issues. Fishermen, scientists and managers divide up the sea to delimit stock units, species ranges, nursery and fishing grounds, faunal boundaries and political jurisdictions. Biological, political, social and economic criteria are all used in establishing closed and restricted areas, delineating regional management zones and community specific grounds, and in setting area/stock specific management measures (e.g. quotas, minimum landing sizes, gear zones, etc.). The delimitation and configuration of these areas can lead to dissonance in fisheries management, particularly when the criteria used for management decisions affecting the spatial distribution of fishing are not those which fishermen consider to be critical. This paper discusses some of the criteria by which fishermen divide up the sea, compares these criteria to some of those used in fisheries management, and discusses potential implications.
\end{abstract}

Key Words: Fishing areas, management, statistical area

\section{Introduction}

As fishermen ${ }^{1}$ often say, "fish have tails". This means that the idea of owning a piece of the ocean for harvesting purposes is often considered impractical, as most finfish and shellfish species move or migrate from one location to another ${ }^{2}$. Nonetheless, the delimitation of areas of the sea is common practice in fisheries management, particularly in addressing issues associated with the selectivity of fishing gear for fish sizes and species concurrences. Fishermen, scientists and managers divide up the sea to delimit stock units, species ranges, nursery and fishing grounds, faunal boundaries and political jurisdictions. Biological, political, social and economic criteria are all used in establishing closed and restricted areas, delineating regional management zones and community specific grounds, and in setting area/stock specific management measures (e.g. quotas, minimum landing sizes, gear zones, etc.).

The delimitation and configuration of these areas can lead to dissonance in fisheries manage- ment, especially when the criteria used for management decisions affecting the spatial distribution of fishing are not those which fishermen consider to be critical. In developing and implementing Fishery Management Plans (FMPs) in the Northeastern United States, a variety of spatial divisions are considered. These include the Hague Line delimiting USA from Canadian waters; the 200 mile Exclusive Economic Zone (EEZ) boundary; the boundary between state and federal waters; Fishery Management Council regions; International Commission for the Northwest Atlantic Fisheries (ICNAF)/Northwest Atlantic Fisheries Organization (NAFO) and United States (USA)/Northeast Fisheries Science Center (NEFSC) statistical areas; fish stock boundaries; and fishing patterns.

This paper begins with a description of key international, national, regional, and state boundaries used in fisheries management in the Northeast United States. It then examines the interaction of fishermen's territorial behaviour and conceptions of critical variables influencing their spatial fishing patterns with some common spatial divisions used

1 There is a debate within social science circles over the appropriateness of a gender-specific term such as "fishermen". However, in the Northeast United States most harvesters are men and even those who are women tend to prefer the title "fisherman". Since this paper concentrates on the Northeast, the gender-specific term is used.

2 In many small scale societies, nonetheless, communities or tribal or family groups do own or at least possess exclusive access rights to marine territories (McGoodwin, 1990; McCay and Acheson, 1987). Among industrialized nations, Japan manages its inshore fisheries through territories owned by community cooperatives (Matsuda and Kaneda, 1984; Ruddle and Akimichi, 1984). 
in fisheries management, and discusses potential areas of dissonance. Finally, it describes some of the current spatially-based management measures being implemented or considered in the Northeastern United States which offer promising avenues for limiting such dissonance.

Data on fishermen's criteria and fishing behaviour were gathered through site visits to ports and interviews with fishermen, computer database searches, and literature reviews. The computer searches involved two National Marine Fisheries Service (NMFS) databases, "weigh out" and "permit". Information on management measures in the Northeast was drawn from FMPs, Environmental Impact Statements (EISs), and notes taken at public meetings where fisheries management issues were discussed.

\section{Fisheries Management in the United States}

In the United States, NMFS is the government agency charged with overseeing management of the nation's marine fisheries in the EEZ. NMFS supplies scientific advice for and approves/disapproves FMPs, or portions of FMPs, created by Regional Fishery Management Councils.

Council members consist of representatives from NMFS, the member states' agencies charged with regulating coastal marine fishing, and members of the public appointed by the member states' Governors (chief executive at the state level). The private citizens represent the various states within each region, as well as diverse groups with an interest in fishing; most commonly, fishing vessel owners, recreational harvesters and fish processors. The precise background of the members varies from region to region and over the life of each Council. The Northeastern seaboard of the USA is overseen by the New England (NEFMC) and Mid-Atlantic (MAFMC) Councils. The New England Council has management responsibility from Maine to Connecticut, and the Mid-Atlantic Council from New York to Virginia (see Fig. 1).

\section{International, National, Regional and State Boundaries}

There are a number of legally-defined spatial boundaries which must be taken into account for fisheries management in the Northeastern United States. These include EEZs, the borders between state and federal waters, and Council region boundaries. These boundaries are often partially based on ecological and fisheries criteria, but are also influenced by other concerns (including ease of administration and enforcement).

Fishing patterns comprised a large portion of the discussions and testimony considered when deciding the appropriate location for the Hague Line. The ultimate placement of the Hague Line, however, was not based on fishing practices (Churchill, 1993) because fisheries issues could not easily be resolved between the parties. Similarly, the distinction between state waters and federal waters has only marginal relationship to fishermen's own inshore/offshore distinction ${ }^{3}$.

Though roughly based on biological factors such as faunal boundaries, the precise location of the boundary between New England and the MidAtlantic Council regions at the Connecticut-New York border appears designed to minimize political disputes over jurisdiction and to facilitate data collection (Halliday and Pinhorn, 1990). Further, administration of fisheries requires coordination among states and between state and federal governments. Setting the Council region boundaries at a state line facilitates this coordination, since no state is divided between the New England and MidAtlantic regions.

There are numerous statistical areas defined for the Northeast United States coast. At the most aggregate level the areal boundaries were originally defined by ICNAF and subsequently adopted by NAFO conventions (see Fig. 2). In theory, the NAFO demarcations correspond to general fish stock boundaries, whether based on fish density (Rounsefell, 1948) or stock composition (Côte, MS 1953). However, very few stocks have geographical distributions exactly coinciding with these demarcations (Halliday and Pinhorn, 1990). Thus, fisheries and fishing were important considerations when statistical areas were being developed. Yet it was administrative and enforcement concerns such as the need for relatively uniform size and configuration which governed boundaries in the end (Halliday and Pinhorn, 1990). Ease of administration requires that jurisdictions should be discrete and hierarchical. Enforceability concerns necessitate that when areas are used as a management tool they must be as large as possible, with clean straight borders.

\footnotetext{
3 Fishermen's concept of the division between offshore and inshore is somewhat fluid, but can be approximated as occurring at about 20 miles offshore. Management is more likely to use an existing administrative division such as the 12 mile territorial sea. This could be seen in one option which was considered for Amendment 5 to the Northeast Multispecies Fishery Management Plan where inshore night fishing was to be prohibited and inshore was in fact designated as within 12 miles of shore.
} 


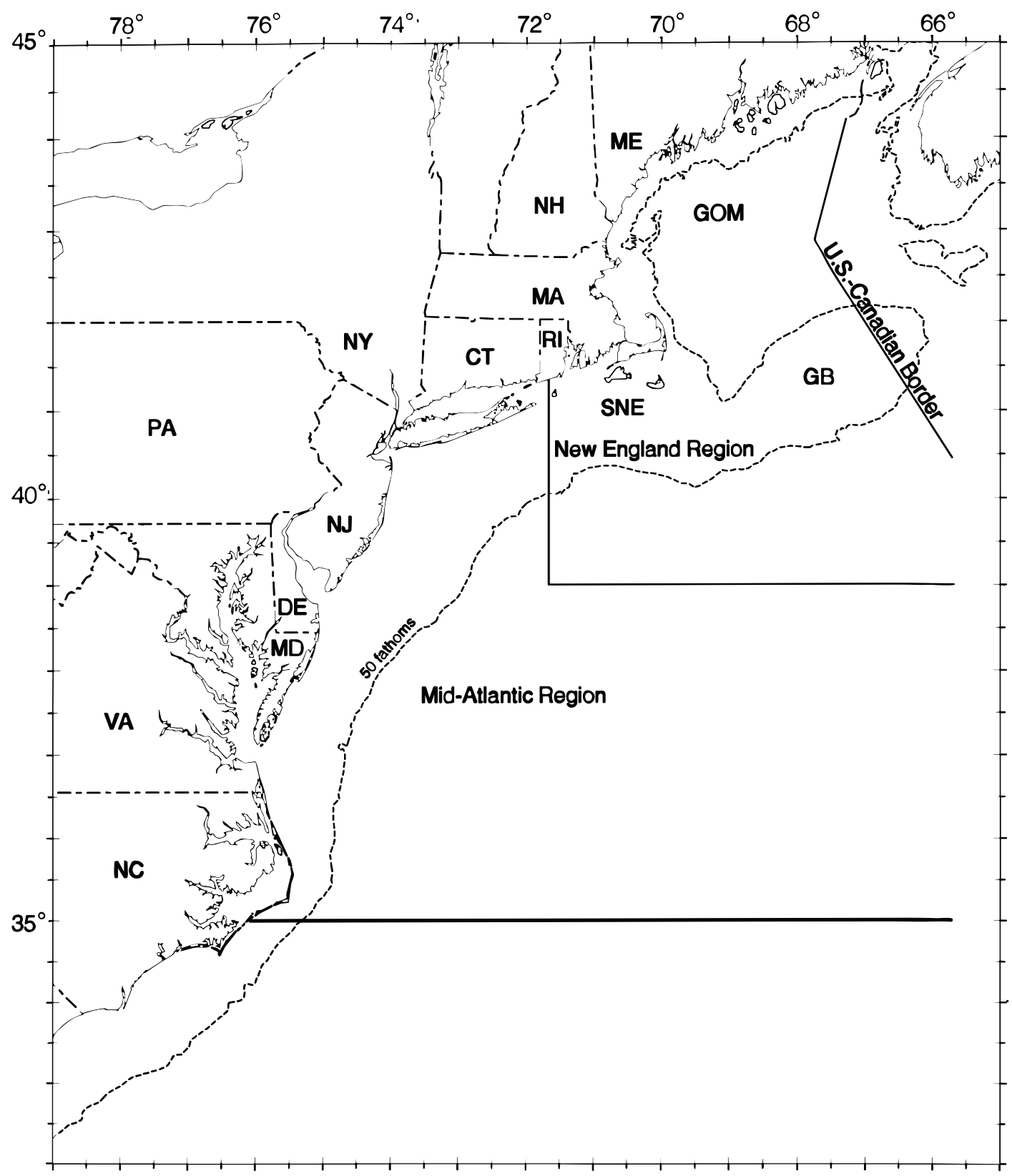

Fig. 1. United States Fishery Management Regions in the Northeast.

\section{Materials and Methods}

\section{Site Visits and Field Interviews}

The field portion was conducted during the months of April and July of 1993 in the Northeast United States ports of: Stonington and Portland, Maine; Portsmouth, Rye and Seabrook, New Hampshire; Boston, Gloucester, New Bedford and Chatham, Massachusetts; and Point Judith, Rhode Island. A one-day visit was made to each of the nine ports to speak with fishermen about their fishing grounds and fishing practices. A total of 38 fishermen were interviewed and 22 drew maps. See Table 1 for a breakdown by port, gear/target species, and vessel length. Those drawing maps included 3 different groundfish/other finfish trawl fishermen, 5 groundfish/dogfish gillnet fishermen, 5 fishermen who use a seasonal mix of groundfish gillnets and small shrimp or scallop trawls along with some longlining or urchining, and 1 part-time lobster fisherman. Apart from the lobsterman, all fishermen were full-time. Vessels of those who drew maps 


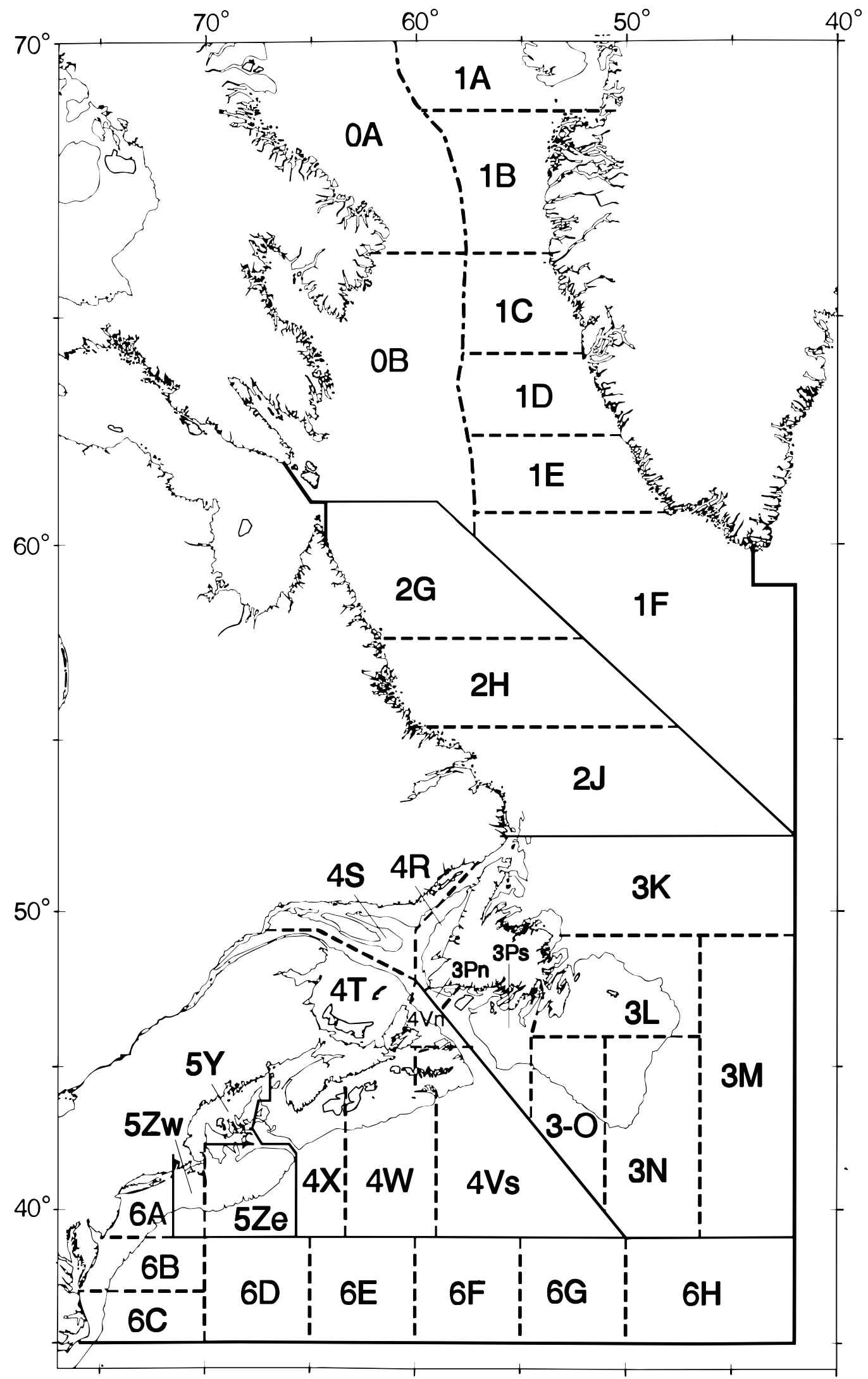

Fig. 2. NAFO Subareas, Divisions and Statistical Reporting Areas (from Halliday and Pinhorn, 1990). 
ranged in size from $30 \mathrm{ft}$ to $95 \mathrm{ft}$, with 16 being $60 \mathrm{ft}$ or less in length and 6 being over $60 \mathrm{ft}^{4}$.

These ports were chosen because they are significant ports in terms of landings and value and/or they are representative of a large subset of ports having special characteristics such as predominant use of an annual round, significant ethnic fishing populations, specialization in a particular style of fishing, or presence of a large fish auction. See Table 2 for 1993 port characteristics. New Bedford, Portland, Point Judith, and Gloucester have a consistent presence in the NMFS commercial landings database ("weigh out", see below) from 1964 to present. These ports also all ranked in the top ten ports for landed value in the Northeast in 1993, with New Bedford and Portland being numbers one and two, respectively. Newport, Boston and Chatham are also within the top 25 of 225 ports with recorded landings. Boston, Portland and New Bedford all possess auctions ${ }^{5}$. Chatham, Portsmouth and Stonington are small boat ports. Boston, New Bedford, Portland and Gloucester are primarily large boat ports. Rockland, Newport and Point Judith are medium boat ports. Point Judith and Newport fish a different mix of species than the other ports, with fewer of the traditional groundfish and more summer flounder, squid, butterfish, and scup. Stonington and Chatham are most likely to fish an annual round based on changing gear. New Bedford is characterized by Portuguese trawl fishermen and Norwegian scallop fishermen. Gloucester fishermen are primarily Italian and fish with trawlers. Portsmouth and Stonington are gillnet ports. Chatham specializes in bottom longlines and gillnets. These ports thus represent the range of key fishing patterns in the Northeast.

Fishermen were asked for basic demographic data and their opinions on different types of management measures, and requested to create maps of where they fished by season and species - using tracing paper laid over NOAA nautical charts. A complete set of charts for the Northeast was available, and fishermen chose the chart they wished to use. While a number of fishermen were in the midst of unloading during the interviews and thus did not have time to draw maps, only one fisherman hesitated about the idea of drawing a map. He consented, but did so on the condition that his map not be shown to other fishermen. No one refused to be interviewed.

\section{The "Weigh out" System}

In the Northeast, NMFS has since 1964 collected information on landings. Through 1993 these data were collected via a network of 32 federal and state port agents located in the major ports. The agents routinely collect "weigh outs" (individual vessel sales receipts) at the point of first sale. This is done on a daily basis in the principal ports and through weekly and monthly visits to other ports. Another aspect of the port agents' data collection activities included voluntary interviews with vessel operators and/or crew during the time when the fish are landed or sold. These "interview records" contain the most reliable information on variables such as gear type, fishing location, and effort. The percentage of trips interviewed varied considerably by port, size of vessel and length or type of trip. Since April 1994 port agents no longer conduct interviews, however, many fisheries (groundfish, summer flounder, sea scallops) are now under a mandatory logbook system which provides generally similar data.

Virtually all of the landings recorded are associated with the type of gear which produced them. However, in some of the smaller ports it is often difficult to associate landings with a particular vessel or trip. Similarly, vessels under 5 gross registered tons (GRT) are called under-tonnage and are not distinguishable in the "weigh out" system as individual vessels; rather they are entered under a group identification code.

Much data are available by USA/NEFSC statistical area (Area) (see Fig. 3). These vary in size from 2 degrees by 2 degrees (Area 639) to an irregular shape approximately 1 degree by 30 minutes (Area 539). Interviewed trip data are available by quarter degree square beginning in 1975. Some data are available by ten minute square, primarily after 1981. A trip where fishing occurred in more than one Area or quarter degree square can be distinguished as a "split trip"6.

In addition to the port agent interview data, interviews conducted in the "sea sampling" program are also entered in the "weigh out". Since 1989 a large-scale sea sampling program has been in place in the Northeast region of the United States in which trained scientific observers are sent to sea aboard commercial vessels. The observers collect information on the catch and by-catch (quantity,

\footnotetext{
${ }^{4}$ Peterson and Smith (1981) while conducting research in Massachusetts found a significant behavioral division between vessels of $60 \mathrm{ft}$ and under or 40 GRT and under, which tended to fish inshore (within 20-25 miles of the coast) on single day trips, and larger vessels which tended to fish offshore on multiple day trips.

5 The Boston auction opened in 1914 and the Portland auction in 1986. New Bedford has had a series of auctions, covering the period from the 1940s through present.

6 A trip may be "split" due to a number of reasons: more than one area per trip, more than one quarter degree square per trip, more than one gear per trip, more than one mesh size per trip, or more than one port of landing per trip.
} 


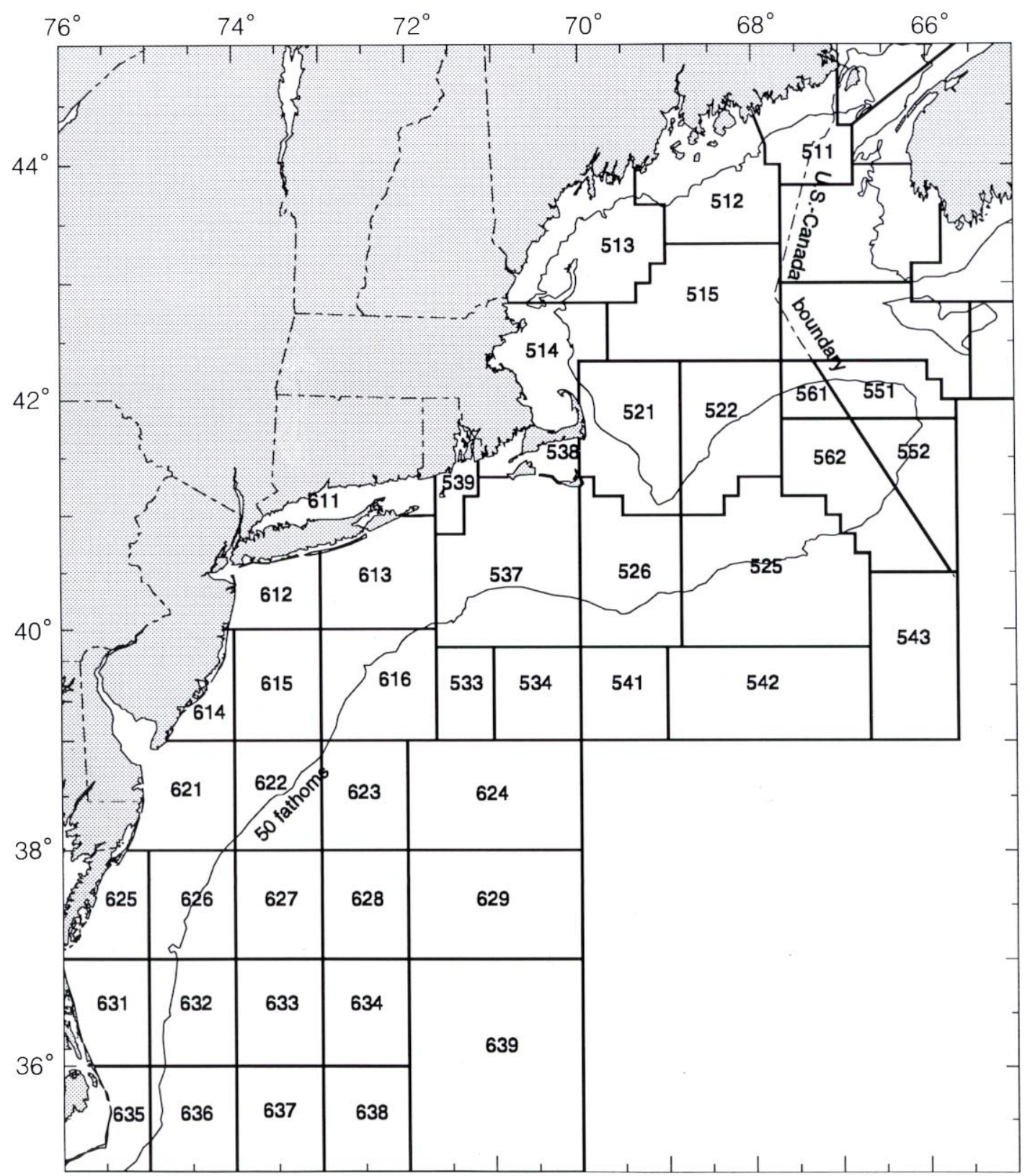

Fig. 3. USA/NEFSC Statistical Areas.

species composition, fish lengths and weights, and discards) as well as record other data on the vessel, gear and fishing operations. The number of fisheries and vessels covered has increased consistently since the program's inception. In 1989 only otter trawl, shrimp trawl and gillnet vessels were included. In 1993, in addition to these, sampled gear types were longline, tuna trawl, sea scallop dredge and lobster pot.

Data from all "weigh out", "sea sampling" and logbook interviewed trips are examined here. An- nual data from 1964 through 1993 were examined with regard to numbers of NMFS statistical areas fished per trip, broken out by port, gear type and vessel size. Because vessel length was not recorded in the database until 1982, vessel size was assigned by tonnage class, using the tonnage class categories commonly used by NMFS: under-tonnage or tonclass 1 (0-4 GRT); tonclass 2 (5-50 GRT); tonclass 3 (51-150 GRT); tonclass 4 (151500); tonclass 5 (501-1 000 GRT); and tonclass 6 (1 001-2 000 GRT). Tonclasses 1 and 2 combined approximate the small versus large vessel 
distinction of 0-40 GRT versus 41+ GRT developed by Peterson and Smith (1981) as one gloss for small inshore day boats versus large offshore trip vessels (Footnote 2). All ports, gears and vessel sizes were examined. However, when a particular category contained fewer than 30 records it was deleted from the analysis.

\section{The Permit System}

In the Northeast, any vessel fishing in a fishery for which there is an FMP must be permitted for that fishery. Originally, these permits were issued in perpetuity, but since 1987 they have been issued for fixed periods (usually a year) and must be renewed at the end of each period. Data listed on the permit include vessel and gear descriptions, the owner's address, the vessel's home port, and the vessel's primary port of landing (self-defined by the applicant). Fishermen may list ports which are not in the Northeast region. There is no charge nor, in most cases, any performance requirements to qualify for a permit and, therefore, the number of permitted vessels in a given fishery generally exceeds the number of active vessels. On their permit forms fishermen may list multiple gears per permit, and many fishermen possess permits for more than one fishery. Permits were examined for 1993 as an additional way of determining if field interviewed fishermen were representative of their ports. In addition, data for 1987 through 1993 were analyzed to determine the degree to which fishermen list their home port as their primary port of landing.

\section{Results}

\section{Site Visits and Field Interviews}

The scale and detail of the fishing grounds identified by fishermen during the port interviews varied considerably. Some fishermen indicated areas which encompassed most of the Northeast coast and said they made little attempt to target by species. Others drew numerous small areas, each of which was specific to a certain time of year and species mix. None of the maps corresponded in even rough ways to statistical areas, management regions, or political boundaries.

The only mention of such boundaries were disparaging comments on the Hague line which since October 1984 divided U.S. and Canadian waters where the respective 200 mile limits previously overlapped. The Hague Line placed some portions of Georges Bank and other traditional grounds out of the reach of the USA fishermen. Nevertheless, the Northeast Peak of Georges, on the Canadian side of the Hague Line, remains firmly embedded in many fishermen's conception of available fishing area. Despite the Hague Line being in effect for a decade, fishermen constantly refer to the unfairness of its imposition and continue to propose alterations.

For example, the owner of a $65 \mathrm{ft}$ Gloucester dragger noted, "if there is a line, and a closure of 50 miles on one side ${ }^{7}$, then there should be another closure for 50 miles on the other side, because the fish will just swim from the closed area on one side of the line to the open area on the other, and the Canadians benefit." The owner of an $86 \mathrm{ft}$ Boston dragger commented that what is frustrating to him is that he "sees" haddock just over the line in Canadian waters. "From the Hague line to Nova Scotia is a more productive area than from Boston to the Line. There's something about the bottom contour and maybe other factors. The fish don't cross the Hague Line... The Canadians are hitting the fish before they get here. You hear the Canadians talking [on the radio]... It would really help if the Hague Line could be extended from Grand Mannan down, 20 miles along the line (67 degrees). The Canadians don't fish there anyway." Scallop vessels also believe the Hague Line to be unfair and often fish along it, and occasionally over it, as demonstrated by several occasions in the early-1990s when scallop vessels were fined for fishing on the Canadian side of the Line.

Both vessel size and gear type appear to influence the type of grounds mapped; and because certain sizes and gears are more prevalent in large and urban ports versus small and rural ports, map types are also related to port. Smaller vessels have inherently smaller ranges than larger vessels and tend to fish small, well defined niches. For example, the owner-operator of a $60 \mathrm{ft}$ otter trawler out of Point Judith said that in late-summer, when the inshore fishery is in the doldrums, he may make 24 trips to below the Dumping Area, for whiting ${ }^{8}$ (see Fig. 4). In the autumn, there are scup northwest of the closed area. In spring there are winter flounder off Block Island, and in late spring whiting and flounder are in Block Island Sound. He also designated scattered other areas as "year round" for either, "flounder, squid, scup", "whiting, squid, flounder", "whiting, fluke, scup", or "whiting, flounder" indicating the relative abundance of different species in each location. The owner-operator of a $40 \mathrm{ft}$

\footnotetext{
7 He refers here to Area II, a US region which has generally been closed to fishing during late-winter and spring to allow haddock to spawn unmolested, and is currently closed year round. Currently Canada also enforces a spawning closure.

8 See Table 3 for scientific names of species mentioned in the text.
} 


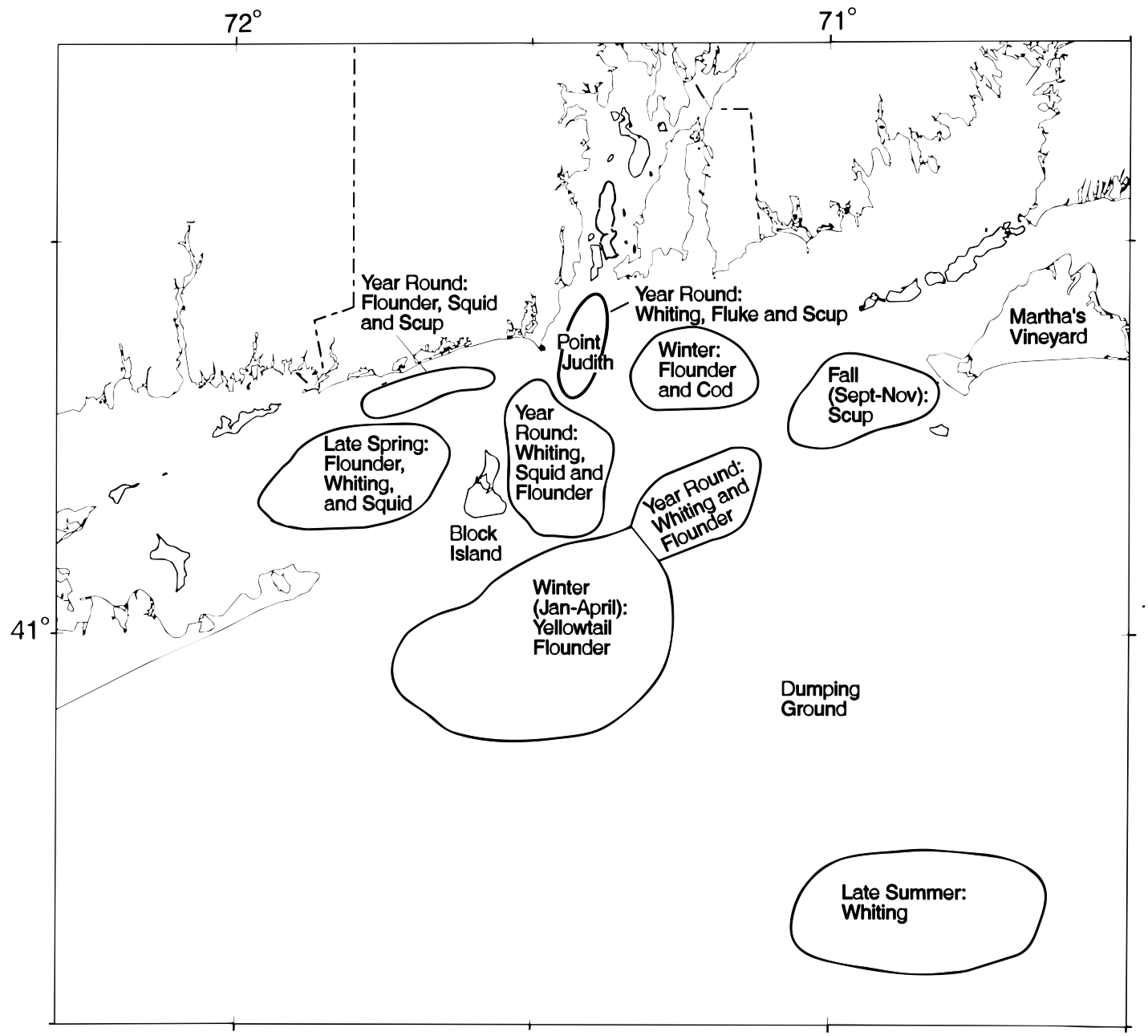

Fig. 4. Example fisherman's map of annual round of fishing, based on NOAA Chart 12300.

gillnetter out of Portsmouth stated, "inshore day gillnetters are almost as territorial as lobstermen."9

Turning to large vessels, an $86 \mathrm{ft}$ otter trawler out of Boston groundfishes primarily for cod "from the Gulf of Maine to the Great South Channel". In the summer he and his crew fish on the northern portion of Georges Bank and on hard bottom offshore (Jeffreys Ledge, Fippenies Ledge, Platts Bank), often along the Hague Line. In the Spring they go to Nantucket Shoals and off the coast of New York. Another large vessel, a $95 \mathrm{ft}$ groundfish otter trawler, distinguished hard versus soft bottom, and a tendency to fish more inshore in winter. But much of the Northeast Coast is simply fished "year round" (see Fig. 5).
Size also interacts with gear type and numbers of different gears used. Dewar (1983) noted that small boats often rely on gear switching, unlike large boats for whom such switching is frequently prohibitively expensive. Gillnetters were the most likely of those interviewed to have an "annual round" wherein they change target species and gear by season. The ability to change gear is related to the relatively small size of gillnet vessels (very few are larger than tonclass 2 or $45 \mathrm{ft}$ ), and to the similar deck configurations necessary using gillnets and longlines. In the Northeast, for instance, 93\% of gillnet vessels fish with other gear for $20 \%$ of the year. In contrast, otter trawlers do not do significant amounts of fishing with other gears (U.S. DOC., 1994). The owner of a $42 \mathrm{ft}$ Stonington

9 Bisack (MS 1995) found (using sea sampling data) that in New England sink gillnet fishermen from adjacent ports tend to have fished in the same area. She has distinguished 4-5 separate fishing territories associated with groups of adjacent ports. 


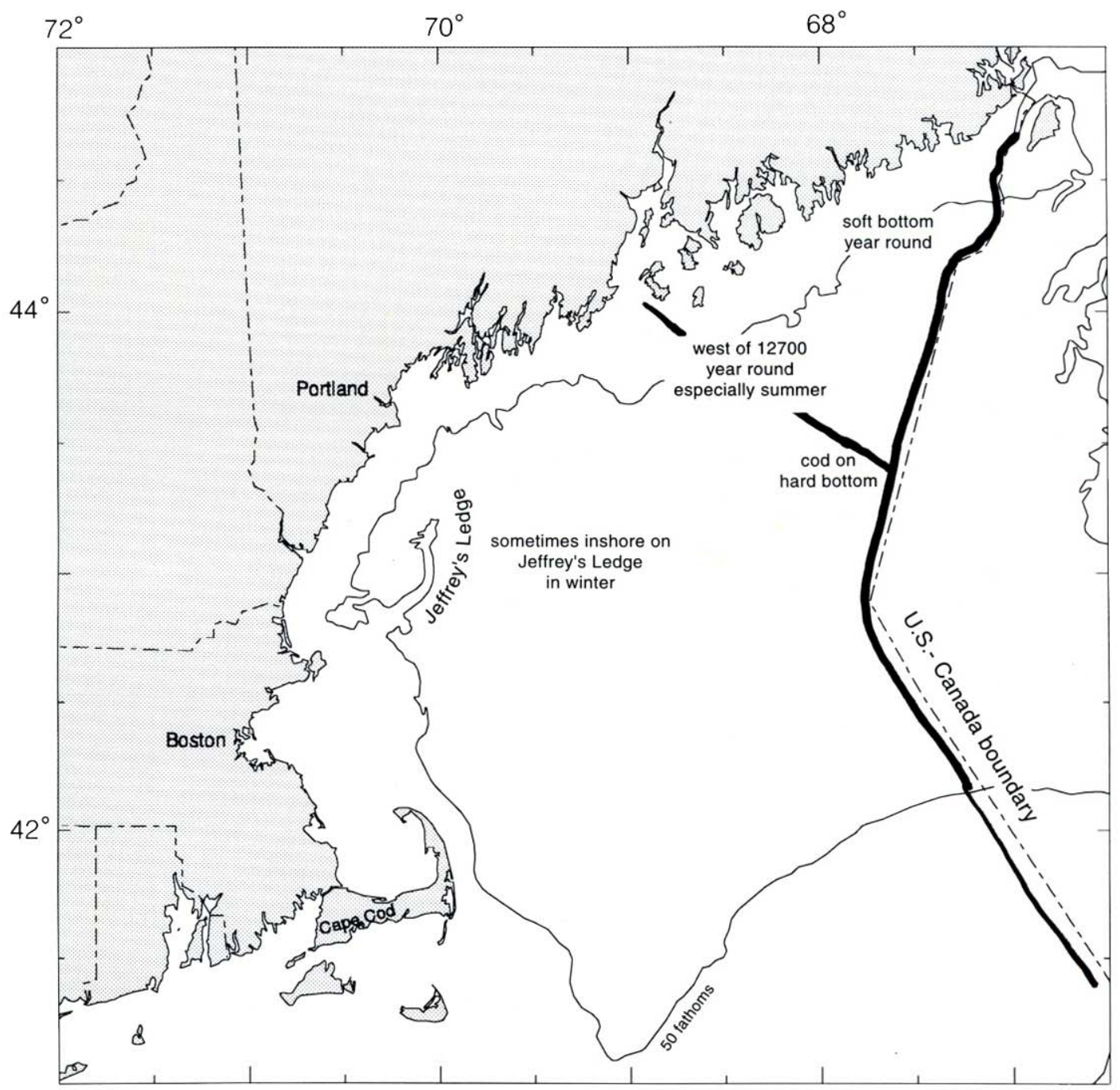

Fig. 5. Example fisherman's map of annual round of fishing, based on NOAA Chart 13260.

gillnetter fishes for cod from May through October, and also brings in some pollock and hake. In the winter he scallops. A Stonington man who owns 4 small boats says he has done gillnetting, clamming, lobstering, musseling and hauling bait. During winter and early-spring, these boats engage in inshore scalloping, groundfish gillnetting and sometimes shrimping. Two of the boats are now going hag fishing. For the last 2-3 years he has been going longlining from the end of November to April. Said the owner of a $42 \mathrm{ft}$ Maine gillnetter, "it's too hard to switch to dragging". Some small draggers, though, do have an annual round, generally involving groundfishing and shrimping. The owner of a $45 \mathrm{ft}$ otter trawler from Seabrook says, "the key to a small dragger is versatility. Some years you catch cod, haddock and yellowtail founder all year. Sometimes you shrimp in the winter. There are 4-5 different things we go for (including large and small mesh groundfish, shrimp and tuna) and all have different nets."

Gear can also interact with area fished and ideas of territoriality due to bottom topography. Trawlers frequently noted hard versus soft bottom on their maps. Said the owner of an $86 \mathrm{ft}$ dragger from Boston, "even with electronics you still need to know the bottom". The owner of a $78 \mathrm{ft}$ mixed species trawl in Point Judith said, "we need to be able to switch from one fishery to another. I have six different nets to do six different things. From New Bedford south it's like this. From New Bedford north it's either groundfish or scallop, one dimensional."

As well, changes in fishing technology can alter territorial patterns, sometimes creating gear conflicts. Trawl fishermen who frequent the hard bottom of the Gulf of Maine rely heavily on "rock hop- 
pers" (roller gear) to prevent torn nets. Before the invention of rock hoppers, draggers were unable to fish hard bottom without considerable loss of gear; these areas were exclusive to gillnets and other stationary gear. Gear conflicts have resulted from this technologically-based behavioral change. Draggers report that, "gillnetters block off whole areas for themselves" or "are souring the bottom with lost nets", while gillnetters say trawlers destroy their gear. And again, size and gear interact. A Maine small boat gillnetter, for instance, says, "small draggers are not a problem. They are too small to get on our gear or tow through it. The big guys though, think the high fliers are goal posts! They just drive right through."

Most of the fine scale maps were associated with small inshore vessels in smaller ports. This is consistent with research showing that true territoriality is most commonly associated with the use of stationary or fixed gears and is more likely to be found in small, community-based, inshore fisheries (Cordell, 1989; Schlager, 1990). Davis (1984), though, did describe a case in Nova Scotia where different portions of the sea, both inshore and offshore, were delegated to specific gear types. Finally, Miller and Van Maanen (1981) noted, "many of the Gloucester boats (both inshore and offshore) have fished the same grounds for years and their charts reflect this fact for they are full of markings indicating safe lanes and alleys." In this case, it may be that Gloucester's close ethnic Sicilian community functions as a small enclave within the larger community of Gloucester (Doeringer et al., 1986).

Personal preferences and family characteristics also play a role in determining the specific target species and vessel sizes that fishermen concentrate on, with resulting implications for types of fishing grounds and ranges. Some fishermen simply like or dislike certain species or gear types; according to one fisherman "each fisherman has a forté, so not everybody will fish for everything". The owneroperator of a $65 \mathrm{ft}$ dragger out of Gloucester, Massachusetts says that in winter he fishes first for cod, pollock and haddock in inshore waters from Cape Cod north along the Boston traffic lane and then out to Murray Basin. Only if fishing is poor will he go further offshore - around Wilkinson Basin - and fish for flatfish, because "flatfish are boring." A Stonington, Maine gillnetter, with a $40 \mathrm{ft}$ boat says he catches urchins in the winter and could live off urchining now, but doesn't want to - too boring and he doesn't like working with the divers. A gillnetter from Seabrook, New Hampshire "tried dragging, but I liked gillnetting better. It's more selective." The owner of a small trawl vessel in Seabrook tried gillnetting, but switched to trawling because he "liked the quality of the product better."

Smaller boats are more likely to make singleday trips and large vessels to make multiple day trips. Many fishermen have very strong feelings about the choice of day versus trip fishing, due to issues such as time spent with family (especially when children are young) and predictability of schedule $^{10}$ (Binkley, 1990; Gatewood and McCay, 1990; Pollnac and Poggie, 1988; Apostle, 1985). The 36 year old owner of a $78 \mathrm{ft}$ trawler that makes 2-5 day trips, said that he used to do 9-11 day trips all the time but has tried to be around more since his kids were born. Similarly the owner of a $44 \mathrm{ft}$ trawler likes day fishing because he can easily take off for day activities and is home when his kids arrive from school. In contrast, a single fisherman who owns a $57 \mathrm{ft}$ otter trawler says he tried day fishing but didn't like it, "getting up in the middle of the night to go out, coming home in the evening, falling asleep, and then getting up to do it all over again". Miller and Van Maanen (1981) noted that in Gloucester the most important division among fishermen is between inshore and offshore draggermen (otter trawlers).

\section{The "Weigh Out"}

The plurality of all interviewed trips fished within a single Area. However, the percentages (see Tables 4, 5 and 6) of trips to a single Area, and average number of Areas per trip (See Tables 7, 8 and 9) varied considerably across port, gear and vessel size, as well as to some extent over the 19641993 period. New England ports are more heterogeneous in their behaviour than Mid-Atlantic ports; all of whom are highly likely to fish in a single Area only. This may, however, be related to the relatively larger size of some of the Areas in the Mid-Atlantic rather than to actual differences in fishing behaviour.

Within New England, vessels in the ports of Boston, Gloucester and New Bedford are the most likely to range over a number of Areas, though for Gloucester, and to a lesser extent Boston, this tendency decreases considerably over time while New Bedford remains more constant. One factor that may explain these differences is that scallop trawl behaviour remains more constant over time than groundfish trawl behaviour. Groundfish trawls ex-

\footnotetext{
10 There is some division by age among the fishermen with respect to day versus trips boats as well, with younger men more likely to work on the long trip boats and older men, near retirement, more likely to work day boats. Said one fisherman in his mid-thirties about his decision to leave a freezer boat for a boat which makes 2-4 day trips," I'm not 25 anymore".
} 
hibit a modest trend toward fishing fewer Areas per trip. The presence of scallop trawls in New Bedford would mitigate the groundfish trawl changes. New Bedford vessels are primarily scallop trawls, groundfish trawls and scallop dredges. Gloucester vessels are primarily groundfish trawls and whiting gillnet vessels. Boston vessels are primarily groundfish trawls.

Stationary gears, as might be expected, show fewer Areas per trip than mobile gear. The exception in the mobile gear category is scallop trawls. This may be related to the relative size of scallop dredges and trawls. According to permit data, the average tonnage for a scallop trawl in 1993 was 34 GRT (small vessel), as opposed to 59 GRT for scallop dredges. Data on fishing behaviour by vessel size indicate a clear distinction between small vessels (tonclasses 1 and 2) and large vessels, with small vessels fishing fewer Areas. All vessel sizes, however, appear to be fishing fewer areas today than in the past, with the possible exception of tonclass 1 vessels. Statistical tests are required, however, in order to confirm whether this is a significant trend for the smallest vessels.

Even in cases of multiple Areas fished per trip, however, the specific Areas are virtually all adjacent, e.g. Area 613 and Area 537, Area 616 and Area 537, Area 522 and Area 562, Areas 616, 537 and 526 (see Fig. 3). On trips which fished entirely within one Area, the degree to which fishing occurred in more than one quarter degree square varies over time (see Table 10). Vessels seem to be fishing more quarter degree squares, though they are often fishing fewer Areas. This may indicate movement toward more fine scale targeting, perhaps due to recent regulations in the groundfish and scallop fisheries which limit the number of days a vessel can fish.

\section{The Permit System}

Over the 1987 to 1993 period, fishermen consistently list the same home port and primary port in approximately $70 \%$ of cases ${ }^{11}$. This is consistent across vessels permitted under three of the major New England FMPs: groundfish, scallop and lobster (see Table 11). In 1993, this can be broken out by size as $17 \%$ of tonclass 1 vessels, $63 \%$ of tonclass 2 vessels, $14 \%$ of tonclass 3 vessels and $6 \%$ of tonclass 4 vessels. Small vessels are thus more likely than large vessels to state that they land in their home ports. This trend also holds true when examined by state (see Table 12).

\section{Discussion}

Preliminary weigh out, permit and field interview data confirm the importance of port, gear and vessel size in influencing fishermen's spatial movements at sea. Work remains to be done with regard to further examination of quarter degree square data, examination of consistency in specific Areas fished by individual vessels, and on the influence of target species (see Gabriel, 1996, this volume). Significance tests should also be conducted for the trends highlighted here.

\section{Current Management Measures and Implications for Management}

When scientific sampling and management regions do not coincide with fishing grounds, it becomes difficult to create datasets which fishermen understand and trust. When management regimes and jurisdictions conflict with the continued use of these grounds, non-compliance risks increase. Recognizing this, Northeast managers, scientists and fishermen are beginning to work more closely on measures relating to area closures and sub-regional management.

A number of current management measures in the Northeast and elsewhere build in some way upon territoriality in fishing behaviour. Total Allowable Catch (TAC) legislation in international treaties and in national legislation has meant that the statistical regions have often become management regions as well. Different combinations of Divisions, sub-Divisions and time periods have been used for TACs for stocks of different species (Halliday and Pinhorn, 1990). Within the USA, TACs are increasingly being included in programs which have other primary governance mechanisms - simply as a backstop. These too must be designated for specific regions in order to allow for enforcement and achieve the desired effect on the resource; and these regions may not correspond to what fishermen would consider to be reasonable based on their knowledge of fish behaviour.

TACs demarcate the sea only indirectly, i.e. through the use of either statistical areas or state or federal waters as zones within which certain amounts of fish may be taken. However, failure to take into account fishermen's ranges and traditional fishing patterns can lead to dispute. In the Northeast, the summer flounder fishery is currently governed by a TAC divided into percentage shares allocated to states in the region. Initially, these shares

\footnotetext{
${ }^{11}$ Lower numbers in 1987 seem to be due primarily to blank fields as the new database system was implemented, rather than to real differences in levels of matching.
} 
were non-transferable. Fishermen in the summer flounder fishery in the USA, however, often land in a state different from the one in which they live or in which their boat is registered. The States began to complain that their quotas were being filled by nonresidents. This led to allowing quota trading among states. While there are some economic rent issues exacerbated by such trading, the practice does recognize the actual behaviour of fishermen and attempt to incorporate it into regulations.

Closed areas can be vital to rehabilitating habitat and providing refugia for stocks in decline. In the Northeast, area closures have gained in importance in recent years. Like quotas, though, they can disrupt the traditional annual round of fishermen by forcing a switch to different species or different gear, or different home port. Many factors will be involved in which of these choices is made. Level of community attachment will figure into whether or not migration is chosen, with day fishermen and fishermen from close-knit rural or ethnic communities being less willing to leave home. Draggers will be less likely to choose different gear. Closed areas however, make sense to fishermen in a way that quotas do not. Fishermen have a very strong aversion to throwing overboard anything that has already come on deck, especially if it is already dead, not withstanding the very high discard rate of non-economic species (see Murawski, 1996, this volume). They do however, generally recognize the need to protect spawning fish and juveniles. Further, to the extent that closed areas take into account fishermen's actual fishing patterns they will be better accepted, though not necessarily as feasible to administer and enforce.

Areas of restriction by gear are also in use in the Northeast. There are designated areas, for instance, where small mesh (under 6 inches) can be used for groundfish fisheries. Elsewhere in the region small mesh is banned for groundfish. Such closures are another measure which is more in line with existing fisheries practices. Increased overall crowding on the grounds has led to the abandonment of or conflict over many traditionally gear-specific areas, but there exists the possibility of building on and officially institutionalizing some of these spatial divisions. Again, however, complex regimes which allow certain gears at certain times are difficult to enforce.

Amendment 5 to the offshore lobster FMP specified four separate management areas. These are based to a large extent on traditional fishing grounds; i.e. they take into account which vessels (by port and gear) fish primarily in what territorial areas. Each zone has its own Effort Management Team (EMT) consisting of lobstermen, scientists and managers. This EMT, while only consultative to the Lobster Committee of the NEFMC, is charged with recommending the specific management measures to be adopted within its zone.

Similarly, one of the alternatives proposed for Amendment 5 to the groundfish FMP (though not an alternative that was implemented) was to divide the Northeast into three regions: the Gulf of Maine (GOM), Georges Bank (GB) and Southern New England (SNE). Each would have had somewhat distinct management rules, based on the differing species mixes, vessel behaviours, and ocean bottom topography of each region.

One of the alternatives initially discussed for Amendment 7 to the groundfish FMP (though never fully developed) created nine separate sub-regions and seven gear groups. Proposed by the NEFMC Groundfish Oversight Committee (Committee), vessels were to be regulated via time/area/gear closures which would open and close each sub-region to specific gear groups by quarter. The specific gears included in each group, and the dimensions and borders of the areas were based on industry practice, and on NMFS data on fishing patterns, stock ranges and stock densities. This proposal was eventually discarded by the Committee as too complicated to be enforceable, and thus not included among alternatives taken to Public Hearing ${ }^{12}$.

In a similar vein, the Gear Conflict Advisory Committee (convened jointly by the New England and Mid-Atlantic Fishery Management Councils) proposed a resolution in early November 1994, which would have designated separate areas by Loran lines, season, and depth for fixed gear, mobile gear and drift gear, with buffer zones in between and some areas unrestricted. This measure was not adopted by the Councils. Also discussed, though not sent on to the Councils as resolutions, were zones based on vessel sizes (e.g. no vessels over $60 \mathrm{ft}$ inside 25 miles; no vessels over $85 \mathrm{ft}$ inside 50 miles; and so forth) and a ban on all fishing west of $70^{\circ} \mathrm{W}$ except by hook boats.

Finally, current gillnet vessel time/area closures for Harbor Porpoise protection (part of Amendment 5 to the groundfish FMP) are designed in part on

\footnotetext{
12 When developing an FMP or Amendment, the Regional Council must hold a series of Public Hearings on a set of alternative measures. Based in part on the public comments, and in part on the Council's expertise and on information supplied by Council and NMFS staff, the Council subsequently decides on a single alternative which they send to NMFS for approval.
} 
existing fleet territoriality. Bisack (MS 1995) found that, in New England, sink gillnet fishermen from adjacent ports of landing tend to have fished in the same area. She distinguished $4-5$ separate fisheries territories associated with groups of adjacent ports. Additional refinements of the placement and boundaries of these areas are being discussed at meetings convened with managers, scientists and fishermen.

\section{Conclusion}

The primary management regions and statistical sampling areas used by managers and scientists are often constructed on the basis of different types and scales of data than those used by fishermen. The fact that scientists collect some of their data on non-commercial vessels and may use different criteria from fishermen can lead to poor communication. Yet, especially when creating seasonally closed areas or gear and species-specific measures (e.g. to address species and size selectivity issues), not only is fishermen's knowledge of ecosystem dynamics valuable, but compliance should be easier if the boundaries of the area form a logical subset of the fishermen's own cognitive maps of the sea (see Ostrom (1990) and Libecap (1989) for good theoretical discussions of cooperation and compliance).

These incompatibilities may be one reason (though others certainly abound) for the lack of communication and sense of isolation that fishermen feel with regard to managers and scientists. And yet, there are many potentially overlapping and complementary areas of knowledge between fishermen and scientists which could lead to mutual support rather than antagonism. Certainly, in the Northeast, increasing efforts have been made to respond to fishermen's criticisms of areal boundaries and seasons.

The problem in many of these cases, of course, is that if regulations attempt to conform closely with the all complex distinctions among fishermen and fishing patterns, they become increasingly difficult to enforce and may require re-organization of the existing management institutions. The challenge is to discern which patterns to build upon and which not. Recent experiences in the Northeast (also see McCay and Creed, 1989), and attempts at cooperative science and co-management in Canada (Pinkerton, 1989), Norway (Jentoft and Kristofferson, 1989) and elsewhere offer some guidelines for future efforts to include local knowledge and ability in the formulation and implementation of effective management.

\section{References}

APOSTLE, R. 1985. Work satisfaction and community attachment among fishermen in southwest Nova Scotia.
Can. J. Fish. Aquat. Sci., 42: 256-267.

BINKLEY, M. 1990. Work organization among Nova Scotian offshore fishermen. Human Organization, 49(4): 395405.

BISACK, K. MS 1995. "1994 and 1995 by-catch estimates of Gulf of Maine Harbor porpoise in the sink gillnet fishery". NMFS, Northeast Fisheries Science Center, Protected Species Branch.

CHURCHILL, R. R. 1993. Fisheries issues in maritime boundary delimitation. Marine Policy., 17(1): 44-57.

CORDELL, J. 1989. A sea of small boats: customary law and territoriality in the world of inshore fishing. Report No. 62. Cambridge, MA: Cultural Survival.

CÔTE, J. MS 1953. Subdivision of Subareas. ICNAF Meeting Document, No. 18, Serial No. 90, 2 p.

DAVIS, A. 1984. Property rights and access management in the small boat fishery: a case study from southwest Nova Scotia. In: Atlantic Fisheries and Coastal Communities: Fisheries Decision-Making Case Studies. C. Lamson and A. Hanson (eds.). Halifax, Nova Scotia: Dalhousie Ocean Studies Programme, p. 133164.

DEWAR, M. 1983. Industry in Trouble: economics and politics of the New England fisheries. Cambridge, MA: MIT Press.

DOERINGER, P, P. MOSS, and D. TERKLA. 1986. The New England Fishing Economy. Amherst: University of Massachusetts Press.

GABRIEL, W. L. 1996. Factors influencing technological interactions in Mid-Atlantic Bight groundfish fisheries. J. Northw. Atl. Fish. Sci., this volume.

GATEWOOD, J., and B. McCAY. 1990. Comparison of job satisfaction in six New Jersey fisheries: implications for management. Human Organization, 49: 14-25.

HALLIDAY, R. G., and A. T. PINHORN. 1990. The delimitation of fishing areas in the Northwest Atlantic. J. of Northw. Atl. Fish. Sci., 10: 1-51.

JENTOFT, S., and T. KRISTOFFERSON. 1976. Fishermen's co-management: the case of the Norwegian fishery. Human Organization, 48(4): 355-365.

LIBECAP, G. D. 1989. Contracting for Property Rights. New York: Cambridge University Press, $132 \mathrm{p}$.

MATSUDA, Y., and Y. TANEDA. 1984. The seven great fisheries incidents in Japan. In: Maritime Institutions in the Western Pacific. K. Ruddle and T. Akimichi (eds.). Senri Ethnological Studies No. 17. Osaka, Japan: National Museum of Ethnology, p. 159-181.

MCCAY, B. J., and J. ACHESON (eds.). 1987. The Question of the Commons: the culture and ecology of communal resources. Tucson: University of Arizona Press, $439 \mathrm{p}$.

MCCAY, B., and C. CREED. 1989. Dividing up the Commons: co-management of the U.S. surf clam fishery. J. S. Thomas, L. Maril, and E. P. Durrenberger (eds.). Marine Resource Utilization: A Conference on Social Science Issues Mobile, AL: University of South Alabama.

MCGOODWIN, J. R. 1990. Crisis in the World's Fisheries: people, problems, and policies. Stanford: Stanford University Press, $231 \mathrm{p}$.

MILLER, M., and J. VAN MAANEN. 1981. Boats don't fish, people do: some ethnographic notes on the federal management of fisheries in Gloucester. James Acheson (ed.). Essays on Social and Curtural Aspects of New England Fisheries, NSF Final Report, Vol. II. Grant No. AER 77-06018, p. 27-53.

MURAWSKI, S. A. MS 1996. Factors influencing by-catch and discard rates: analyses from multispecies/ multifishery sea sampling. J. Northw. Atl. Fish. Sci., 
(this volume).

OSTROM, E. 1990. Governing the Commons: the evolution of institutions for collective action. New York: Cambridge University Press, $280 \mathrm{p}$.

PETERSON, S. B., and L. J. SMITH. 1981. Small-scale commercial fishing in New England. Woods Hole Oceanographic Institute Technical Report No., 8172. Woods Hole, MA: WHOI, $43 \mathrm{p}$.

PINKERTON, E. (ed.) 1989. Co-operative Management of Local Fisheries: new directions in improved management and community development. Vancouver, B.C.: University of British Columbia Press, 299 p.

POLLNAC, R. B., and J. J. POGGIE, JR. 1988. The structure of job satisfaction among New England fishermen and its implications for management. American Anthropologist, 90: 888-901.

ROUNSEFELL, G. A. 1948. Development of fishery statis- tics in the North Atlantic. U.S. Fish and Wildlife Service Special Science Report, 47, $27 \mathrm{p}$.

RUDDLE, K., and T. AKIMICHI (eds.). 1984. Maritime institutions in the Western Pacific. Senri Ethnological Studies, No. 17. Osaka, Japan: National Museum of Ethnology, $327 \mathrm{p}$.

SCHLAGER, E. 1990. Model specification and policy analysis: the governance of coastal fisheries, Ph.D. dissertation. Workshop in Political Theory and Policy Analysis, Indiana University, Bloomington, Indiana, $247 \mathrm{p}$.

TERKLA, D., and P. DOERINGER. 1995. Troubled Waters: economic structure, industrial policy, and fisheries trade. Toronto: Univ. of Toronto Press.

U.S. DOC (U.S. Dept of Commerce) 1994. "Status of the fishery resources off the northeastern United States for 1993". NOAA Technical Memorandum NMFS-F/ NEC-108, $140 \mathrm{p}$. 
TABLE 1. Field interviewed fishermen (numbers following "maps", indicate vessel lengths).

\begin{tabular}{|c|c|c|c|c|c|c|}
\hline & $\begin{array}{l}\text { Groundfish } \\
\text { Trawl }\end{array}$ & $\begin{array}{l}\text { Dogfish or } \\
\text { Groundfish } \\
\text { Gillnet }\end{array}$ & $\begin{array}{l}\text { Swordfish } \\
\text { Draft Gillnet }\end{array}$ & $\begin{array}{c}\text { Groundfish } \\
\text { Gillnet/shrimp/ } \\
\text { Scallop }\end{array}$ & Scalloper & $\begin{array}{l}\text { Lobster or } \\
\text { Fish Traps }\end{array}$ \\
\hline Stonington & & & & $\begin{array}{l}5 \text { interviews } \\
5 \text { maps, 40- }\end{array}$ & & \\
\hline Rockland & & & & & & $\begin{array}{l}3 \text { interviews } \\
1 \text { map, } 30 \mathrm{ft}\end{array}$ \\
\hline Portland & \multicolumn{2}{|c|}{$\begin{array}{l}3 \text { interviews } \\
2 \text { maps, } 60,71 \mathrm{ft}\end{array}$} & & & & \\
\hline Portsmouth & $\begin{array}{l}1 \text { interview } \\
1 \text { map, } 38 \mathrm{ft}\end{array}$ & $\begin{array}{l}4 \text { interviews } \\
4 \text { maps, } 38-44 \mathrm{ft}\end{array}$ & & & & \\
\hline Rye & & $\begin{array}{l}1 \text { interview } \\
0 \text { maps }\end{array}$ & & & & \\
\hline Seabrook & $\begin{array}{l}1 \text { interview } \\
1 \text { map, } 45 \mathrm{ft}\end{array}$ & $\begin{array}{l}1 \text { interview } \\
0 \text { maps }\end{array}$ & & & & \\
\hline Gloucester & \multicolumn{2}{|c|}{$\begin{array}{l}2 \text { interviews } \\
2 \text { maps, 65, } 95 \mathrm{ft}\end{array}$} & & & & \\
\hline Boston & $\begin{array}{l}4 \text { interviews } \\
1 \text { map, } 86 \mathrm{ft}\end{array}$ & & & & & \\
\hline New Bedford & $\begin{array}{l}1 \text { interview } \\
1 \text { map, } 60 \mathrm{ft}\end{array}$ & $\begin{array}{l}1 \text { interview } \\
0 \text { maps }\end{array}$ & $\begin{array}{l}1 \text { interview } \\
0 \text { maps }\end{array}$ & & $\begin{array}{l}3 \text { interviews } \\
0 \text { maps }\end{array}$ & \\
\hline Chatham & & $\begin{array}{l}2 \text { interviews } \\
1 \text { map, } 66 \mathrm{ft}\end{array}$ & & & & $\begin{array}{l}1 \text { interview } \\
0 \text { maps }\end{array}$ \\
\hline Point Judith & $\begin{array}{l}3 \text { interviews } \\
3 \text { maps, } 59,60\end{array}$ & $78 \mathrm{ft}$ & & & & \\
\hline
\end{tabular}

\section{KEY for Tables:}

$\begin{array}{ll}\text { Pland } & \text { Portland. Maine } \\ \text { Rland } & \text { Rockland, Maine } \\ \text { Bton } & \text { Boston, Massacusetts } \\ \text { Glstr } & \text { Gloucester, Massachusetts } \\ \text { NBed } & \text { New Bedford, Massachusetts } \\ \text { Ptwn } & \text { Provincetown, Masachusetts } \\ \text { Swch } & \text { Sandwich, Massachusetts } \\ \text { Nport } & \text { Newport, Rhode Island } \\ \text { Pt J } & \text { Point Judith, Rhode Island } \\ \text { Pt. Pl } & \text { Point Pleasant, New Jersey } \\ \text { CMay } & \text { Cape May, New Jersey } \\ \text { Wwd } & \text { Wildwood, New Jersey } \\ \text { Ocn } & \text { Ocean City, Maryland } \\ \text { Hton } & \text { Hampton, Virginia } \\ \text { Nflk } & \text { Norfolk, Virginia } \\ \text { Chtg } & \text { Chincoteague, Virginia } \\ \text { CpCh } & \text { Cape Charles, Virginia } \\ \text { Nnws } & \text { Newport News, Virginia } \\ \text { Hpsh } & \text { Hampshire, New Hampshire } \\ \text { Gport } & \text { Greenport, New York } \\ \text { Mntk } & \text { Montauk, New York } \\ \text { HBay } & \text { Hampton Bays, New York } \\ \text { Chtm } & \text { Chatham, Massachusetts } \\ \text { Ston } & \text { Stonington, Maine } \\ \end{array}$

$\begin{array}{ll}010 & \text { Bottom Longline } \\ 020 & \text { Hand Gear } \\ 030 & \text { Harpoon } \\ 040 & \text { Pelagic Longline } \\ 050 & \text { Fish Bottom Trawl } \\ 052 & \text { Scallop Trawl } \\ 056 & \text { Bottom Pair Trawl } \\ 058 & \text { Shrimp Bottom Trawl } \\ 080 & \text { Floating Traps } \\ 100 & \text { Sink Gillnet } \\ 115 & \text { Large Pelagic Draft Gillnet } \\ 120 & \text { Purse Seine } \\ 132 & \text { Scallop Dredge } \\ 142 & \text { Pound Net, Fish } \\ 160 & \text { Danish Seine } \\ 170 & \text { Midwater Pair Trawl } \\ 181 & \text { Fish Pots/Traps } \\ 200 & \text { Offshore Lobster Pots/Traps } \\ 360 & \text { Scottish Seine } \\ 385 & \text { Mussel Dredge } \\ 400 & \text { Surf Clam/Ocean Quahog Dredge } \\ 500 & \text { Runaround Gillnet }\end{array}$


TABLE 2. Site visit port characteristics for 1993.

\begin{tabular}{|c|c|c|c|c|c|c|c|c|c|c|c|c|}
\hline W/O Data & Pland & Rland & Ston & Bton & Glstr & Chtm & NBed & Ptmth & Sbrk & Nport & PtJ & All \\
\hline Tot. Trips & 4571 & 121 & 925 & 863 & 14866 & 6735 & 7443 & 3606 & 1696 & 1486 & 6201 & 59518 \\
\hline $\begin{array}{l}\text { Tot. Lbs. } \\
{ }^{*} 100 \mathrm{~K}\end{array}$ & 78.6 & 31.7 & 5.2 & 9.8 & 63.1 & 10.2 & 64.4 & 6.3 & 1.6 & 10.5 & 57.8 & 1596 \\
\hline $\begin{array}{l}\text { Tot. \$ Value } \\
{ }^{*} 100 \mathrm{~K}\end{array}$ & 49.1 & 3.2 & 3.6 & 10.8 & 31.3 & 10.2 & 108 & 5.8 & 1.8 & 11.2 & 35.3 & 886 \\
\hline $\begin{array}{l}\text { No. Intv } \\
\text { Trips TC1 }\end{array}$ & 58 & 0 & 2 & 0 & 201 & 202 & 6 & 286 & 79 & 0 & 11 & 1545 \\
\hline $\begin{array}{l}\text { No. Intv } \\
\text { Trips TC2 }\end{array}$ & 545 & 37 & 92 & 149 & 842 & 557 & 41 & 166 & 38 & 118 & 238 & 4311 \\
\hline $\begin{array}{l}\text { No. Intv } \\
\text { Trips TC3 }\end{array}$ & 467 & 30 & 0 & 370 & 722 & 0 & 1643 & 21 & 0 & 399 & 1032 & 9116 \\
\hline $\begin{array}{l}\text { No. Intv } \\
\text { Trips TC4 }\end{array}$ & 131 & 2 & 0 & 266 & 444 & 0 & 1344 & 0 & 0 & 83 & 452 & 5998 \\
\hline $\begin{array}{l}\text { No. Intv Trips } \\
\text { Gear } 050\end{array}$ & 806 & 48 & 0 & 737 & 1371 & 64 & 1771 & 167 & 85 & 39 & 1422 & 8752 \\
\hline $\begin{array}{l}\text { No. Intv Trips } \\
\text { Gear } 100\end{array}$ & 233 & 0 & 88 & 0 & 470 & 401 & 25 & 1 & 360 & 44 & 56 & 2109 \\
\hline $\begin{array}{l}\text { No. Intv Trips } \\
\text { Gear } 132\end{array}$ & 13 & 21 & 3 & 7 & 0 & 0 & 1097 & 1 & 2 & 0 & 3 & 1748 \\
\hline $\begin{array}{l}\text { No. Intv Trips } \\
\text { Gear } 010\end{array}$ & 59 & 0 & 0 & 6 & 51 & 250 & 1 & 0 & 2 & 0 & 12 & 386 \\
\hline $\begin{array}{l}\text { No. Intv Trips } \\
\text { Gear } 200\end{array}$ & 0 & 0 & 2 & 0 & 2 & 0 & 76 & 42 & 0 & 0 & 141 & 368 \\
\hline \multicolumn{13}{|l|}{ Permit Data } \\
\hline No. Vessels TC1 & 5 & 0 & 1 & 5 & 51 & 72 & 6 & 19 & 26 & 2 & 20 & 1243 \\
\hline No. Vessels TC2 & 56 & 17 & 25 & 710 & 191 & 71 & 44 & 50 & 26 & 27 & 96 & 3617 \\
\hline No. Vessels TC3 & 23 & 2 & 0 & 128 & 46 & 0 & 107 & 1 & 3 & 14 & 43 & 930 \\
\hline No. Vessels TC4 & 11 & 3 & 0 & 38 & 19 & 0 & 100 & 0 & 0 & 2 & 13 & 331 \\
\hline
\end{tabular}

TABLE 3. Scientific names of species mentioned in the text.

\begin{tabular}{ll}
\hline \hline Common name & Scientific name \\
\hline Butterfish & Peprilus triacanthus \\
Clam & Spisula solidissima \\
Cod, Atlantic & Gadus morhua \\
Crab, Stone & Menippe mercenaria \\
Dogfish, Spiny & Squalus acanthias \\
Flounder, Summer/Fluke & Paralichthys dentatus \\
Flounder, Winter & Pleuronectes americanus \\
Flounder, Yellowtail & Pleuronectes ferrugineus \\
Goosefish/Monkfish & Lophius americanus \\
Haddock & Melanogrammus aeglefinus \\
Hake & Urophycis spp. \\
Hake, Silver/Whiting & Meluccius bilinearis \\
Harbor Porpoise & Phoceona phoceona \\
Lobster, American & Homarus americanus \\
Mackerel, Atlantic & Scomber scombrus \\
Pollock & Pollachius virens \\
Scallop, Sea & Placopecten magellanicus \\
Scup & Stenotomus chrysops \\
Shrimp & Penaeus spp. \\
Skate & Raja spp. \\
Squid & Illexillecebrosus, Loligo pealii \\
Urchin, Green Sea & Strongylocentrotus droebachiensis \\
\hline
\end{tabular}


TABLE 4. Percentage of trips fishing only one USA/NEFSC statistical area, by port.

\begin{tabular}{|c|c|c|c|c|c|c|c|c|c|c|c|c|}
\hline & Pland & Rland & Bton & Glstr & NBed & Ptwn & Swch & Nport & Pt. J & Pt. PI & CMay & Wwd \\
\hline 1964 & 72 & 59 & 36 & 37 & 31 & 67 & & & & & & \\
\hline 1965 & 72 & 61 & 36 & 45 & 42 & 72 & & & 69 & & & \\
\hline 1966 & 82 & 64 & 40 & 44 & 46 & 73 & & & 68 & & & \\
\hline 1967 & 84 & 57 & 40 & 42 & 44 & 80 & & & 57 & & & \\
\hline 1968 & & 75 & 45 & 38 & 50 & 88 & & & 63 & & & \\
\hline 1969 & & & 55 & 44 & 47 & 85 & & & 63 & & & \\
\hline 1970 & & & 59 & 44 & 46 & & & & 58 & & & \\
\hline 1971 & 73 & & 60 & 62 & 50 & 72 & & 74 & 44 & & & \\
\hline 1972 & 83 & 58 & 65 & 61 & 45 & 75 & & 61 & 61 & 69 & & \\
\hline 1973 & 87 & 59 & 64 & 56 & 53 & 85 & & 63 & 60 & & & \\
\hline 1974 & 92 & 44 & 61 & 62 & 54 & 73 & & 65 & 64 & & & \\
\hline 1975 & 85 & 96 & 57 & 67 & 49 & 70 & 87 & 65 & 64 & & & \\
\hline 1976 & 87 & 71 & 65 & 66 & 52 & 77 & 86 & 66 & 53 & & & \\
\hline 1977 & 86 & 57 & 63 & 58 & 25 & 73 & 87 & 55 & 50 & & & \\
\hline 1978 & 84 & 41 & 45 & 62 & 47 & 71 & 82 & 55 & 56 & 94 & 90 & 100 \\
\hline 1979 & 76 & 60 & 45 & 63 & 38 & 64 & 80 & 49 & 57 & 91 & 94 & \\
\hline 1980 & 92 & 66 & 55 & 70 & 34 & 61 & 78 & 53 & 47 & 96 & 95 & \\
\hline 1981 & 97 & 64 & 57 & 64 & 39 & 69 & 72 & 60 & 45 & & 91 & \\
\hline 1982 & 86 & 65 & 58 & 63 & 35 & 78 & 94 & 66 & 45 & 93 & 94 & \\
\hline 1983 & 84 & 62 & 61 & 64 & 39 & 79 & 89 & 64 & 61 & 92 & 89 & 100 \\
\hline 1984 & 83 & 68 & 67 & 67 & 37 & 81 & 92 & 62 & 62 & 96 & 85 & 95 \\
\hline 1985 & 78 & 74 & 56 & 65 & 41 & 81 & 95 & 59 & 62 & 91 & 91 & 93 \\
\hline 1986 & 81 & 79 & 43 & 69 & 44 & 88 & & 60 & 64 & 91 & 89 & 94 \\
\hline 1987 & 75 & 84 & 52 & 67 & 46 & 87 & & 74 & 64 & 91 & 85 & 94 \\
\hline 1988 & 74 & 84 & 50 & 70 & 45 & 86 & 97 & 74 & 69 & 88 & 79 & 90 \\
\hline 1989 & 80 & 86 & 64 & 67 & 44 & 72 & 100 & 77 & 69 & 91 & 77 & 88 \\
\hline 1990 & 77 & 94 & 70 & 70 & 45 & 93 & 98 & 74 & 63 & 91 & 94 & 100 \\
\hline 1991 & 81 & 95 & 73 & 73 & 47 & 95 & 100 & 73 & 64 & 79 & 61 & 79 \\
\hline 1992 & 83 & 95 & 67 & 74 & 52 & 93 & 100 & 75 & 68 & 66 & 74 & 79 \\
\hline 1993 & 84 & 88 & 70 & 80 & 48 & 90 & 100 & 75 & 67 & 74 & 68 & 78 \\
\hline
\end{tabular}

\begin{tabular}{|c|c|c|c|c|c|c|c|c|c|c|c|c|}
\hline & Ocn & Hton & Nflk & Chtg & $\mathrm{CpCh}$ & NNws & Hpsh & Gport & Mntk & HBay & Chtm & Ston \\
\hline 1982 & 83 & 90 & & 88 & & & & & & & & \\
\hline 1983 & 82 & 90 & 93 & 89 & 79 & 93 & & & & & & \\
\hline 1984 & 86 & 89 & 95 & 92 & 94 & 97 & & & & & & \\
\hline 1985 & 92 & 92 & 92 & 91 & 98 & 95 & 89 & & & & & \\
\hline 1986 & 86 & 93 & 94 & 87 & 83 & 96 & & 95 & 90 & 94 & & \\
\hline 1987 & 87 & 91 & 93 & 87 & 97 & 94 & & & 86 & 93 & 95 & \\
\hline 1988 & 86 & 90 & 97 & 90 & & 92 & & & & 91 & 96 & \\
\hline 1989 & 63 & 90 & 97 & 86 & & 87 & & & & & 100 & \\
\hline 1990 & 96 & 92 & & 95 & & 89 & & & & & 100 & \\
\hline 1991 & 67 & 86 & & 98 & & 92 & 95 & & & & 100 & 94 \\
\hline 1992 & 81 & 91 & & 93 & & 84 & & & & & 99 & 99 \\
\hline 1993 & 90 & 94 & & 97 & & 91 & 95 & & & & 100 & 100 \\
\hline
\end{tabular}

\begin{tabular}{|c|c|c|c|c|c|c|}
\hline & WHbr & $\mathrm{BHbr}$ & SBrtl & Jport & Ptmth & Sbrk \\
\hline 1991 & 77 & 100 & 98 & 93 & & 94 \\
\hline 1992 & 95 & 95 & 95 & 97 & 95 & 94 \\
\hline 1993 & & 98 & 98 & 87 & 87 & 88 \\
\hline
\end{tabular}


TABLE 5. Percentage of trips fishing only one USA/NEFSC statistical areas, by gear.

\begin{tabular}{|c|c|c|c|c|c|c|c|c|c|c|c|c|}
\hline & 010 & 030 & 040 & 050 & 052 & 055 & 058 & 100 & 120 & 130 & 170 & 200 \\
\hline 1964 & 100 & & & 41 & & & & & & 44 & & \\
\hline 1965 & 98 & & & 43 & & & & & & 71 & & \\
\hline 1966 & 95 & & & 43 & & & & & & 83 & & \\
\hline 1967 & 97 & & & 43 & & & & & & 71 & & \\
\hline 1968 & & & & 47 & & & & & & 55 & & \\
\hline 1969 & & & & 49 & & & & & & 66 & & \\
\hline 1970 & 91 & & & 45 & & & & & & 72 & & \\
\hline 1971 & 91 & & & 52 & & & & & & 71 & & \\
\hline 1972 & 92 & & & 56 & & & & & 97 & 65 & & 95 \\
\hline 1973 & 84 & & & 57 & & & & & 100 & 82 & 82 & 99 \\
\hline 1974 & 90 & & & 59 & & & & & 100 & 81 & & 97 \\
\hline 1975 & 98 & 100 & 95 & 55 & & 80 & 85 & 95 & 99 & 76 & 95 & 81 \\
\hline 1976 & 98 & & 94 & 57 & & & 89 & 97 & 94 & 75 & 97 & 75 \\
\hline 1977 & 95 & 100 & & 50 & & & 90 & 95 & 94 & 76 & 98 & 84 \\
\hline 1978 & & 93 & & 53 & & & & 89 & 100 & 78 & 100 & 85 \\
\hline 1979 & & 83 & 82 & 51 & & & & 93 & 100 & 65 & 100 & 90 \\
\hline 1980 & & & 83 & 55 & & & & 95 & 100 & 63 & 98 & 82 \\
\hline 1981 & & & 97 & 54 & & & 92 & 100 & 100 & 66 & 100 & 90 \\
\hline 1982 & & & 92 & 61 & & & 91 & 91 & 100 & 62 & & 94 \\
\hline 1983 & & 95 & 82 & 62 & & & 99 & 90 & 100 & 68 & & 96 \\
\hline 1984 & & & 84 & 63 & 100 & & 88 & 90 & 100 & 64 & & 90 \\
\hline 1985 & & & 82 & 63 & & & 91 & 92 & 100 & 61 & & 91 \\
\hline 1986 & & & 78 & 64 & 95 & & 91 & 93 & 100 & 63 & & 84 \\
\hline 1987 & 87 & & 86 & 63 & 95 & & 81 & 88 & 100 & 64 & & 94 \\
\hline 1988 & 94 & & 90 & 64 & 99 & & 83 & 83 & 100 & 61 & & 92 \\
\hline 1989 & 100 & & 94 & 65 & 95 & & 94 & 88 & 100 & 67 & & 100 \\
\hline 1990 & 100 & & 88 & 66 & 95 & 97 & 91 & 88 & 97 & 68 & & 95 \\
\hline 1991 & 100 & & 87 & 66 & 96 & 95 & 85 & 94 & 100 & 67 & & 95 \\
\hline 1992 & 96 & & 91 & 68 & 98 & 89 & 93 & 93 & 96 & 65 & & 96 \\
\hline 1993 & 100 & & 90 & 72 & 92 & 93 & 95 & 93 & 100 & 66 & & 84 \\
\hline
\end{tabular}

\begin{tabular}{|c|c|c|c|c|c|c|c|c|c|c|}
\hline & 020 & 080 & 115 & 142 & 181 & 360 & 370 & 385 & 400 & 500 \\
\hline $\begin{array}{l}1980 \\
1981\end{array}$ & & & & & & & & & 97 & \\
\hline 1982 & & & & & 99 & & & & 84 & \\
\hline 1983 & & & & 100 & 100 & & & & 88 & \\
\hline 1984 & & 100 & & 100 & 100 & 87 & & & 91 & \\
\hline 1985 & & & & 100 & 99 & 90 & 91 & & & \\
\hline 1986 & & & & & 97 & 86 & & & 89 & 94 \\
\hline 1987 & & 100 & & & & 100 & & & 88 & \\
\hline 1988 & & 100 & & & 96 & 100 & & & 83 & \\
\hline 1989 & 97 & & & & & 95 & & & 100 & 79 \\
\hline 1990 & & & 92 & & 93 & & & 100 & 100 & 100 \\
\hline 1991 & 100 & & & & 96 & & & 100 & 71 & \\
\hline 1992 & 100 & & & & 97 & & & 100 & 76 & \\
\hline 1993 & & & & & 100 & & & & 74 & \\
\hline
\end{tabular}


TABLE 6. Average number of areas fished per trip, by tonclass.

\begin{tabular}{lcccc}
\hline \hline & Tonclass 1 & Tonclass 2 & Tonclass 3 & Tonclass 4 \\
\hline 1964 & & 59 & 36 & 38 \\
1965 & & 63 & 40 & 45 \\
1966 & & 59 & 44 & 49 \\
1967 & & 60 & 40 & 47 \\
1968 & & 62 & 34 & 59 \\
1969 & & 68 & 37 & 63 \\
1970 & & 69 & 40 & 53 \\
1971 & & 69 & 51 & 54 \\
1972 & & 78 & 55 & 62 \\
1973 & & 73 & 56 & 62 \\
1974 & & 77 & 56 & 61 \\
1975 & & 77 & 57 & 59 \\
1976 & & 80 & 54 & 65 \\
1977 & 100 & 77 & 51 & 57 \\
1978 & 100 & 82 & 58 & 55 \\
1979 & 100 & 80 & 51 & 49 \\
1980 & 100 & 79 & 56 & 58 \\
1981 & & 82 & 55 & 57 \\
1982 & 100 & 85 & 60 & 62 \\
1983 & 100 & 88 & 61 & 66 \\
1984 & 99 & 89 & 62 & 69 \\
1985 & 97 & 88 & 63 & 68 \\
1986 & 98 & 89 & 66 & 66 \\
1987 & 99 & 88 & 67 & 67 \\
1988 & 99 & 87 & 67 & 67 \\
1989 & 99 & 90 & 70 & 65 \\
1990 & 100 & 90 & 68 & 65 \\
1991 & 97 & 92 & 64 & 62 \\
1992 & 98 & 93 & 68 & 65 \\
1993 & 94 & 94 & 69 & 68 \\
\hline & & & &
\end{tabular}


TABLE 7. Average number of areas fished per trip, by port.

\begin{tabular}{|c|c|c|c|c|c|c|c|c|c|c|c|c|}
\hline & Pland & Rland & Bton & Gistr & NBed & Ptwn & Swch & Nport & Pt. J & Pt. PI & CMay & Wwd \\
\hline 1964 & 1.3 & 1.7 & 2.2 & 2.4 & 2.3 & 1.3 & & & 1.4 & & & \\
\hline 1965 & 1.2 & 1.5 & 2.1 & 2.3 & 2.0 & 1.3 & & & 1.3 & & & \\
\hline 1966 & 1.2 & 1.5 & 2.1 & 2.2 & 2.0 & 1.3 & & & 1.4 & & & \\
\hline 1967 & 1.2 & 1.6 & 2.2 & 2.0 & 2.3 & 1.3 & & & 1.4 & & & \\
\hline 1968 & 1.1 & 1.4 & 2.0 & 2.0 & 2.1 & 1.1 & & & 1.4 & & & \\
\hline 1969 & 1.2 & 1.4 & 1.7 & 2.0 & 2.0 & 1.1 & & & 1.5 & & & \\
\hline 1970 & 1.2 & 1.6 & 1.6 & 2.1 & 2.1 & 1.2 & & 1.0 & 1.7 & & & \\
\hline 1971 & 1.4 & 1.9 & 1.6 & 1.6 & 2.0 & 1.3 & & 1.3 & 1.8 & & & \\
\hline 1972 & 1.2 & 1.7 & 1.5 & 1.6 & 1.9 & 1.2 & 1.1 & 1.6 & 1.5 & & & \\
\hline 1973 & 1.2 & 1.8 & 1.5 & 1.7 & 1.8 & 1.1 & & 1.6 & 1.5 & & & \\
\hline 1974 & 1.1 & 2.2 & 1.6 & 1.5 & 1.9 & 1.3 & & 1.6 & 1.4 & & & \\
\hline 1975 & 1.2 & 1.7 & 1.7 & 1.5 & 2.0 & 1.3 & 1.1 & 1.5 & 1.5 & & & \\
\hline 1976 & 1.2 & 1.5 & 1.6 & 1.5 & 2.0 & 1.3 & 1.2 & 1.5 & 1.6 & & & \\
\hline 1977 & 1.1 & 1.7 & 1.6 & 1.7 & 2.1 & 1.3 & 1.1 & 1.7 & 1.8 & & & \\
\hline 1978 & 1.2 & 2.1 & 1.8 & 1.7 & 2.1 & 1.3 & 1.2 & 1.9 & 1.6 & 1.1 & 1.1 & 1.0 \\
\hline 1979 & 1.3 & 1.6 & 1.9 & 1.6 & 2.5 & 1.5 & 1.3 & 2.2 & 1.6 & 1.1 & 1.1 & 1.0 \\
\hline 1980 & 1.1 & 1.5 & 1.7 & 1.5 & 2.5 & 1.5 & 1.3 & 1.8 & 1.8 & 1.0 & 1.1 & 1.0 \\
\hline 1981 & 1.0 & 1.6 & 1.6 & 1.7 & 2.3 & 1.4 & 1.3 & 1.6 & 1.8 & 1.1 & 1.1 & \\
\hline 1982 & 1.2 & 1.5 & 1.6 & 1.7 & 2.4 & 1.2 & 1.1 & 1.5 & 1.8 & 1.1 & 1.1 & \\
\hline 1983 & 1.2 & 1.5 & 1.5 & 1.6 & 2.4 & 1.2 & 1.1 & 1.5 & 1.5 & 1.1 & 1.1 & 1.0 \\
\hline 1984 & 1.2 & 1.5 & 1.4 & 1.6 & 2.5 & 1.2 & 1.1 & 1.6 & 1.6 & 1.1 & 1.0 & 1.1 \\
\hline 1985 & 1.3 & 1.4 & 1.6 & 1.6 & 2.4 & 1.2 & 1.1 & 1.6 & 1.6 & 1.1 & 1.1 & 1.1 \\
\hline 1986 & 1.3 & 1.3 & 2.0 & 1.5 & 2.2 & 1.1 & 1.1 & 1.5 & 1.5 & 1.1 & 1.1 & 1.1 \\
\hline 1987 & 1.3 & 1.2 & 1.7 & 1.5 & 2.2 & 1.1 & & 1.4 & 1.5 & 1.1 & 1.1 & 1.1 \\
\hline 1988 & 1.4 & 1.2 & 1.7 & 1.4 & 2.2 & 1.2 & 1.1 & 1.4 & 1.5 & 1.1 & 1.2 & 1.1 \\
\hline 1989 & 1.3 & 1.1 & 1.5 & 1.4 & 2.2 & 1.3 & 1.0 & 1.3 & 1.4 & 1.1 & 1.3 & 1.1 \\
\hline 1990 & 1.3 & 1.0 & 1.4 & 1.4 & 2.2 & 1.1 & 1.0 & 1.4 & 1.5 & 1.1 & 1.1 & 1.0 \\
\hline 1991 & 1.2 & 1.1 & 1.4 & 1.4 & 2.2 & 1.1 & 1.0 & 1.4 & 1.5 & 1.2 & 1.5 & 1.3 \\
\hline 1992 & 1.2 & 1.1 & 1.4 & 1.3 & 2.0 & 1.1 & 1.0 & 1.3 & 1.4 & 1.4 & 1.3 & 1.3 \\
\hline 1993 & 1.2 & 1.1 & 1.4 & 1.3 & 2.0 & 1.1 & 1.0 & 1.4 & 1.5 & 1.3 & 1.4 & 1.3 \\
\hline
\end{tabular}

\begin{tabular}{|c|c|c|c|c|c|c|c|c|c|c|c|c|}
\hline & Ocn & Hton & Nflk & Chtg & $\mathrm{CpCh}$ & NNws & Hpsh & Gport & Mntk & HBay & Chtm & Ston \\
\hline 1982 & 1.2 & & & & & & & & & & & \\
\hline 1983 & 1.2 & 1.1 & 1.1 & 1.1 & & 1.1 & & & & & & \\
\hline 1984 & 1.2 & 1.1 & 1.1 & 1.1 & 1.1 & 1.0 & & & & & & \\
\hline 1985 & 1.1 & 1.1 & 1.1 & 1.1 & 1.1 & 1.1 & 1.1 & & & & & \\
\hline 1986 & 1.2 & 1.1 & 1.1 & 1.1 & 1.2 & 1.0 & 1.1 & 1.1 & 1.1 & 1.1 & & \\
\hline 1987 & 1.1 & 1.1 & 1.1 & 1.1 & 1.1 & 1.1 & & 1.1 & 1.1 & 1.1 & 1.1 & \\
\hline 1988 & 1.2 & 1.1 & 1.0 & 1.1 & & 1.1 & & & 1.3 & 1.1 & 1.0 & \\
\hline 1989 & 1.2 & 1.1 & 1.0 & 1.2 & & 1.1 & & & & 1.2 & 1.0 & \\
\hline 1990 & 1.0 & 1.1 & & 1.1 & & 1.1 & & & & 1.1 & 1.0 & \\
\hline 1991 & 1.4 & 1.2 & & 1.1 & & 1.1 & 1.1 & & & & 1.0 & 1.1 \\
\hline 1992 & 1.2 & 1.1 & & 1.1 & & 1.2 & 1.0 & & 1.7 & & 1.0 & 1.0 \\
\hline \multirow[t]{2}{*}{1993} & 1.1 & 1.1 & & 1.0 & & 1.1 & 1.0 & & 1.3 & & 1.0 & 1.0 \\
\hline & WHbr & $\mathrm{BHbr}$ & SBrtl & Jport & Ptmth & Sbrk & & & & & & \\
\hline 1991 & 1.2 & 1.0 & 1.0 & 1.1 & 1.2 & 1.1 & & & & & & \\
\hline 1992 & 1.1 & & 1.1 & 1.0 & 1.1 & 1.1 & & & & & & \\
\hline 1993 & 1.1 & 1.0 & 1.0 & 1.1 & 1.1 & 1.1 & & & & & & \\
\hline
\end{tabular}


CLAY: Criteria for Dividing up the Sea

TABLE 8. Average number of areas fished per trip, by tonclass.

\begin{tabular}{lcccc}
\hline \hline & Tonclass 1 & Tonclass 2 & Tonclass 3 & Tonclass 4 \\
\hline 1964 & & 1.6 & 2.3 & 2.1 \\
1965 & & 1.5 & 2.2 & 1.9 \\
1966 & & 1.6 & 2.1 & 1.8 \\
1967 & & 1.6 & 2.4 & 1.8 \\
1968 & & 1.5 & 2.4 & 1.7 \\
1969 & & 1.5 & 2.2 & 1.6 \\
1970 & & 1.4 & 2.3 & 1.7 \\
1971 & & 1.4 & 1.7 & 1.9 \\
1972 & & 1.4 & 1.7 & 1.5 \\
1973 & & 1.4 & 1.7 & 1.6 \\
1974 & & 1.2 & 1.8 & 1.7 \\
1975 & & 1.3 & 1.8 & 1.6 \\
1976 & 1.0 & 1.2 & 1.5 & 1.9 \\
1977 & 1.0 & 1.2 & 1.9 & 1.7 \\
1978 & 1.0 & 1.2 & 1.8 & 1.7 \\
1979 & 1.0 & 1.3 & 1.0 & 1.9 \\
1980 & & 1.2 & 1.9 & 1.7 \\
1981 & 1.0 & 1.2 & 1.8 & 1.7 \\
1982 & 1.0 & 1.1 & 1.8 & 1.6 \\
1983 & 1.0 & 1.1 & 1.8 & 1.5 \\
1984 & 1.0 & 1.1 & 1.7 & 1.5 \\
1985 & 1.0 & 1.1 & 1.6 & 1.6 \\
1986 & 1.0 & 1.1 & 1.6 & 1.5 \\
1987 & 1.0 & 1.1 & 1.6 & 1.5 \\
1988 & 1.0 & 1.1 & 1.5 & 1.6 \\
1989 & 1.0 & 1.1 & 1.6 & 1.6 \\
1990 & 1.0 & 1.1 & 1.6 & 1.6 \\
1991 & 1.0 & 1.1 & 1.5 & 1.5 \\
1992 & 1.1 & 1.1 & 1.5 & 1.5 \\
1993 & & & &
\end{tabular}


TABLE 9. Average number of areas fished per trip, by gear.

\begin{tabular}{|c|c|c|c|c|c|c|c|c|c|c|c|c|}
\hline & 010 & 030 & 040 & 050 & 052 & 055 & 058 & 100 & 120 & 130 & 170 & 200 \\
\hline 1964 & 1.0 & & & 2.1 & & & & & & 2.0 & & \\
\hline 1965 & 1.0 & & & 2.0 & & & & & & 1.4 & & \\
\hline 1966 & 1.0 & & & 2.1 & & & & & & 1.2 & & \\
\hline 1967 & 1.1 & & & 2.1 & & & & & & 1.5 & & \\
\hline 1968 & 1.0 & & & 1.9 & & & & & & 1.7 & & \\
\hline 1969 & 1.0 & & & 1.9 & & & & & & 1.5 & & \\
\hline 1970 & 1.1 & & & 2.0 & & & & & 1.0 & 1.4 & & \\
\hline 1971 & 1.1 & & & 1.8 & & & & & 1.0 & 1.4 & & \\
\hline 1972 & 1.1 & & & 1.7 & & & & & 1.0 & 1.4 & & 1.0 \\
\hline 1973 & 1.1 & & & 1.7 & & & & & 1.0 & 1.3 & 1.2 & 1.0 \\
\hline 1974 & 1.1 & & & 1.7 & & & & & 1.0 & 1.2 & & 1.1 \\
\hline 1975 & 1.0 & & 1.1 & 1.8 & & 1.2 & 1.2 & 1.1 & 1.0 & 1.3 & 1.1 & 1.2 \\
\hline 1976 & 1.0 & & 1.1 & 1.8 & & 1.2 & 1.1 & 1.0 & 1.0 & 1.3 & 1.0 & 1.3 \\
\hline 1977 & 1.1 & 1.0 & 1.3 & 1.9 & & 1.0 & 1.1 & 1.1 & 1.1 & 1.3 & 1.0 & 1.2 \\
\hline 1978 & & 1.1 & 1.2 & 1.8 & & & & 1.1 & 1.1 & 1.3 & 1.0 & 1.2 \\
\hline 1979 & & 1.2 & 1.2 & 2.0 & & & 1.2 & 1.1 & 1.0 & 1.5 & 1.0 & 1.1 \\
\hline 1980 & & 1.1 & 1.2 & 1.8 & & & & 1.0 & 1.0 & 1.6 & 1.0 & 1.2 \\
\hline 1981 & & & 1.0 & 1.8 & & & 1.1 & 1.0 & 1.0 & 1.5 & 1.0 & 1.1 \\
\hline 1982 & & & 1.1 & 1.7 & & & 1.1 & 1.1 & 1.0 & 1.6 & 1.1 & \\
\hline 1983 & & 1.1 & 1.2 & 1.7 & & & 1.0 & 1.1 & 1.0 & 1.6 & 1.0 & 1.0 \\
\hline 1984 & & & 1.2 & 1.7 & & & 1.1 & 1.1 & 1.0 & 1.6 & 1.0 & 1.1 \\
\hline 1985 & & & 1.2 & 1.7 & & & 1.1 & 1.1 & 1.0 & 1.7 & 1.0 & 1.1 \\
\hline 1986 & & & 1.3 & 1.6 & 1.1 & 1.3 & 1.1 & 1.1 & 1.0 & 1.6 & & 1.2 \\
\hline 1987 & 1.1 & & 1.2 & 1.6 & 1.1 & & 1.2 & 1.1 & 1.0 & 1.6 & & 1.1 \\
\hline 1988 & 1.1 & & 1.1 & 1.6 & 1.0 & & 1.2 & 1.2 & 1.0 & 1.7 & & 1.1 \\
\hline 1989 & 1.0 & & 1.1 & 1.6 & 1.1 & & 1.1 & 1.1 & 1.0 & 1.6 & & 1.0 \\
\hline 1990 & 1.0 & & 1.2 & 1.6 & 1.1 & 1.0 & 1.1 & 1.1 & 1.0 & 1.6 & & 1.0 \\
\hline 1991 & 1.0 & & 1.1 & 1.6 & 1.0 & 1.0 & 1.2 & 1.1 & 1.0 & 1.6 & & 1.0 \\
\hline 1992 & 1.1 & & 1.1 & 1.5 & 1.0 & 1.1 & 1.1 & 1.1 & 1.1 & 1.7 & & 1.0 \\
\hline \multirow[t]{2}{*}{1993} & 1.0 & & 1.1 & 1.4 & 1.1 & 1.1 & 1.1 & 1.1 & 1.0 & 1.7 & & 1.2 \\
\hline & 020 & 080 & 115 & 142 & 181 & 360 & 370 & 385 & 400 & 500 & & \\
\hline 1980 & & & & & & & & & 1.0 & & & \\
\hline 1981 & & & & & 1.0 & & & & 1.0 & & & \\
\hline 1982 & & & & & 1.0 & & 1.0 & & 1.2 & & & \\
\hline 1983 & & & & 1.0 & 1.0 & & & & 1.1 & & & \\
\hline 1984 & & 1.0 & & 1.0 & 1.0 & 1.1 & & & 1.1 & & & \\
\hline 1985 & 1.0 & & & 1.0 & 1.0 & 1.1 & & & 1.1 & & & \\
\hline 1986 & & & & & 1.0 & 1.1 & & & 1.1 & 1.1 & & \\
\hline 1987 & & 1.0 & & & 1.0 & 1.0 & & & 1.1 & & & \\
\hline 1988 & & 1.0 & & & 1.0 & 1.0 & & & 1.2 & & & \\
\hline 1989 & & & & & 1.1 & 1.1 & & & 1.2 & 1.0 & & \\
\hline 1990 & & & 1.1 & & 1.1 & & & 1.0 & 1.0 & 1.0 & & \\
\hline 1991 & 1.0 & & & & 1.0 & & & 1.0 & 1.4 & & & \\
\hline 1992 & 1.0 & & & & 1.0 & & & 1.0 & 1.3 & & & \\
\hline 1993 & & & & & 1.0 & & & & 1.3 & & & \\
\hline
\end{tabular}


TABLE 10. Percent of quarter degree squares fished on trips that fished only one USA/NEFSC Statistical Area.

\begin{tabular}{lcc}
\hline \hline & One & Two \\
\hline 1982 & 47 & 52 \\
1983 & 57 & 42 \\
1984 & 48 & 50 \\
1985 & 38 & 58 \\
1986 & 55 & 39 \\
1987 & 47 & 52 \\
1988 & 48 & 48 \\
1989 & 23 & 68 \\
1990 & 27 & 47 \\
1991 & 34 & 65 \\
1992 & 23 & 73 \\
1993 & 15 & 80 \\
\hline
\end{tabular}

TABLE 11. Percentages of home port/primary port matches, all ports.

\begin{tabular}{lcccc}
\hline \hline & All Permits & Multispecies Permits & Scallop Permits & Lobster Permits \\
\hline 1987 & 62 & 65 & 66 & 65 \\
1988 & 70 & 71 & 70 & 72 \\
1989 & 71 & 72 & 70 & 72 \\
1990 & 71 & 72 & 70 & 72 \\
1991 & 71 & 72 & 72 & 73 \\
1992 & 71 & 71 & 73 & 73 \\
1993 & 70 & 70 & 72 & 72 \\
\hline
\end{tabular}

TABLE 12. 1993 percentages of permitted vessels by tonclass: where home port = primary port and all permits.

\begin{tabular}{|c|c|c|c|c|c|c|c|c|c|}
\hline Hport=Pport & TC1 & TC2 & TC3 & TC4 & All Permits & TC1 & TC2 & TC3 & TC4 \\
\hline ME & 14 & 80 & 5 & 2 & & 18 & 76 & 4 & 2 \\
\hline $\mathrm{NH}$ & 38 & 59 & 4 & & & 51 & 47 & 2 & \\
\hline MA & 29 & 51 & 12 & 8 & & 23 & 56 & 13 & 6 \\
\hline CT & 21 & 71 & 7 & 1 & & 24 & 66 & 8 & 2 \\
\hline $\mathrm{RI}$ & 22 & 58 & 16 & 4 & & 33 & 51 & 14 & 3 \\
\hline DE & 26 & 70 & 4 & & & 13 & 67 & 15 & 5 \\
\hline MD & 13 & 52 & 32 & 3 & & 15 & 49 & 31 & 5 \\
\hline NY & 18 & 66 & 15 & 1 & & 16 & 69 & 14 & 1 \\
\hline NJ & 21 & 54 & 19 & 7 & & 22 & 55 & 18 & 7 \\
\hline VA & 3 & 26 & 49 & 22 & & 4 & 33 & 40 & 24 \\
\hline
\end{tabular}


